$ノ$ ノ

\title{
しめ縄加工に適する新たなイネ䏍種素材「伊勢錦」
}

\author{
小林和幸 ${ }^{1)} \cdot$ 河合由起子 ${ }^{1)} \cdot$ 平尾賢一2) 阿部聖一3) ・ 星 豊一 3$)$ \\ (1) 新潟県農業総合研究所作物研究センタ一, 長岡市, 干 940-0826, ${ }^{2}$ 新潟県農業大学校, 西蒲原郡巻町, $\overline{7} 953-0041,{ }^{3}$ 新潟県南蒲原農業改良 \\ 普及センター，三条市，干955-0046）
}

\section{A new rice breeding material 'Isenishiki' suitable for traditional processing straw-works (Shimenawa)}

Kazuyuki Kobayashi ${ }^{1)}$, Yukiko Kawai ${ }^{1)}$, Ken-ichi Hirao ${ }^{2)}$, Seiichi $\mathrm{Abe}^{3)}$ and Toyokazu Hoshi ${ }^{3)}$

(1) Crop Research Center, Niigata Agricultural Research Institute, Nagaoka 940-0826, Japan, ${ }^{2)}$ Niigata Agricultural Junior College, Maki 953-0041, Japan, ${ }^{3)}$ Minamikanbara Agricultural Extension Center, Sanjo 955-0046, Japan)

\section{キーワード : Oryza sativa L., 育種素材, 伊勢錦, ジーン バンク, しめ縄}

\section{1. はじめに}

しめ縄加工用イネ（以下，しめ縄イネと略）の栽培は 生産調整面積に組み入れられ，また中山間地域等に揖い て直接支払制度も適用されることなどから, 新潟県の中 山間地域に打殒る水田機能の維持と地場産業の振興に重 要な役割を果たしている．新潟県に打けるしめ縄イネの 栽培面積は約 200 ha で, 山形県や福島県などとともに全 国有数の生産地となっている.

新潟県内に抢けるしめ縄イネの主な生産地は長野県境 に近い東頸城郡松代町, 中魚沼郡川西町, 西頸城郡能生 町などで, それ呑れ 20〜30 ha の作付けがある. また, 平 坦部の新潟市, 長岡市, 新津市なぞ, 県内各地に加工製 品を取り扱う業者があり, こうした市町村の近隣地域に 执いても数 ha 規模で作付けがなされている.

新潟県で最も多く栽培され，利用されているしめ縄人 ネ品種は「実取らず」と呼ばれる在来種である。「実取ら ず」は最近の戸倉 (2002) の報告にもあるように, 晚生で 長秙, 稈質が柔らかく, 葉色が濃いといら優れたしめ縄 加工特性を有し, しめ縄加工の専用品種として古くから 利用されてきた品種である。

図 1 は主産地の一つである松代町に打けるしめ縄イネ の生産, 加工, 流通の形態を示した模式図である. 松代 町に颃いても「実取らず」が最も多く栽培され, 利用さ れている. 松代町は世界有数の豪雪地として知られて打 り, 消雪の遅れに伴う移植期の遅延により,「実取らず」 の成熟期が登熟晚限に近くなる，そのため，地域全体を

編集委員 : 佐藤洋一郎

2003 年 6 月 2 日受領 2003 年 10 月 7 日受理

Correspondence: kobak@ari.pref.niigata.jp
まかなえる程の十分な種子量を確保することが困難であ る. しかし，松代町には取引のある東京都の業者から，千 葉県内で採種された「実取らず」の種子が毎年 $400 \mathrm{~kg}$ 程 度送付されてくる。関東近県では，「実取らず」の商業的 な栽培が注消隇状態にあることから（戸倉 2002），何 としても産地を確保したいといら大手業者の思惑と, 松 代町に打注生産現場の実状とが相互に補完し合った関 係となっている（図 1).

松代町に抢けるしめ縄加工製品の単年度の販売総額は 6 千万円を超光, コメに次ぐ第 2 位の地位にあり, 商品開 発や装飾・加工で周年の現地雇用を創出するなど，乙め 縄イネ栽培が当該地域の産業振興に果している役割は極 めて大きい，このように新潟県に打死しめ縄関連産業 は，一般的に認識されているような家内工業的な小規模 な形態のものとは大きく異なって扣り, 栽培面積の大き さや従事者数から見ても, 中山間地域の重要な産業とし て確固たる地位を築いている.

しかし，現在のところしめ縄加工に適した品種が「実 取らず」以外にないため, 現場の多くでは収穫・乾燥作 業の集中が深刻な問題となっている. 中山間地域の生産 地の多くは高齢従事者が多い上に，刈り取り適期が 8 月 初旬で最も暑さが厳しい時期にあたることから, 労衝衛 生面からも作期の分散が強く望まれている. しめ縄イネ 栽培地を抱元る地域の農業改良普及センタ一を通じ，こ らした現場の強い要請が当作物研究センターに寄せられ た.

そこで，当作物研究センターが収集し保存してきたイ ネ遺伝資源と, 農業生物資源研究所・ジーンバンクょり 新たに配布を受けたイネ遺伝資源を加兄, 1998 年よりの べ 25 品種・系統の特性調査を実施し, 新たなしめ縄加工 適応品種の探索を行った．その結果，「実取らず」との作 期分散が可能で, 加工特性にも優孔る有望なイネ㕕種素 材を選出することができたので，ここに報告する． 


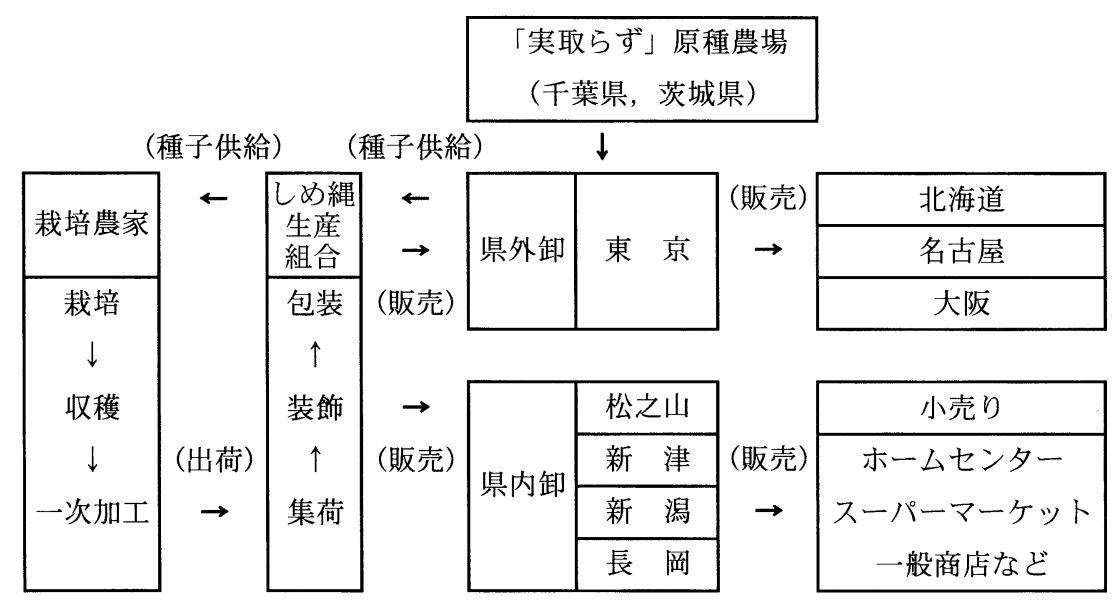

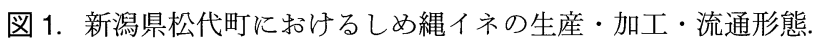

\section{2. 現場ニーズの具体的内容}

\section{1）収穫期の分散}

しめ縄イネの加工適性は次の点に集約される。すなわ ち, (1)生育が旺盛で, 草丈が長いこと, (2)柔軟性に富む こと, (3)葉色が濃く, 葉先の長さが揃らこと, (4)乾燥・保 管時の退色, 劣化が少ないこと, (5)病斑（特に葉いもち 病）が少ないこと，(6)手触りが良いこと，(7)製品に艶が あることである.

従来より用いられてきた「実取らず」は，イネいもち 病に弱いが, それ以外のしめ縄加工特性には極めて優れ, しめ縄加工適応品種として高い評価を得てきた。しかし 近年, 栽培面積の拡大とともに, 作付け集中による弊害 が顕在化してきた.

現地では，「実取らず」の移植時期を移動させるなどの 耕種的な取組みもなされているが，作付けはほぼ限界に 近づいてきている。一方，「実取らず」と作期が競合しな い「コシヒカリ」や，「ビルマイネ」と呼ばれる外来種な ども利用されているが，いもち耐病性や加工特性に問題 がある. また，これらの品種では，山間高冷地に执いて 十分な草丈が確保できないといった事態も生じている.

現地に和ける「実取らず」の収穫適期は 8 月 5 10日 頃 (幼穂形成期 最長秙の幼穂長 $5 \mathrm{~cm}$ 程度, 出穂前 15 〜20 日頃）で, 中山間地域と言えども厳しい暑さの時期 にあたる. 生産現場としては 3 期, すなおち(1) 7 月 $20 \sim 25$ 日頃，(2) 8 月 10 日頃 (「実取らず」)，(3)扮盆過ぎの 8 月 15〜20日頃に収穫期を分散させたいとして扣り，(1) と (3)の時期に収穫が可能で，「実とらず」に匹敵する加工特 性を有するしめ縄加工適応品種が強く求められている.

\section{2）葉の緑色保持}

しめ縄加工製品の色沢は商品価値を左右する最も重要 なポイントである。そこで生産現場では，葉色を濃くす るため, 窒素成分量で $1 \mathrm{~kg} / \mathrm{a}$ といった, かなりの多窒素栽 培を行っている. しめ縄イネは長秙であるが, 幼穂伸長
期のごく初期に収穫してしまらことから，倒伏が問題に なることはない，また，窒素の施用のみでは乾燥・保管 時の退色が早く，艶も劣るとされ，カリやリン酸肥料も 多く投入されている.

収穫したしめ縄イネはイグサ用乾燥機で $70^{\circ} \mathrm{C}, 10$ 時 間乾燥される。しめ縄加工製品の生産は 1 年を通じて行 われることから，膨大な原材料を，刈り取り時の葉の色 沢を保持したまま長期間保管しなければならない，現場 ではこのため, 硫黄燻蒸による酵素失活法や窒素ガス充 填による保管などを試みてきたが，これまでのところ満 足のいく結果は得られていない，現在では特別な処理は せず，湿気，風，光を極力避けるよらな保管をしている が，原料を最良な状態で大量に維持管理するのには限界 がある.そこで, (1)葉色が退色しにくい品種, および(2)栽 培管理も含めた効率的な葉の緑色保持技術（退色抑制技 術）の開発が強く望まれている.

本研究では，こうした現場ニーズに対して，育種学的 な側面から支援するため，「実取らず」との作期分散が可 能で，加工特性にも優れる新たなしめ縄加工適応品種の 探索を行った.

\section{3. 特性調查の方法}

\section{1）耕種法}

新潟県作物研究センター（新潟県長岡市）に括いて 1998 2002 年の 5 カ年間でのべ 25 品種・系統を供試し た.ここで有望と認められた品種・系統を現地実証試験 （新潟県東頸城郡松代町）に供試した.

播種はいずれも 4 月第 5 半旬，移植は 5 月第 4 半旬で 中苗を手植えした。作物研究センタ一に打ける 1 次ス クリーニングでは，基肥として窒素，リン酸，カリを成 分量で各 $0.4 \mathrm{~kg} / \mathrm{a}$ を施用し，追肥は施用しなかった．現 地に拈ける 2 次スクリーニングでは慣行栽培に準じて 行い，基肥として窒素，カリを成分量で各 $0.4 \mathrm{~kg} / \mathrm{a}$, 追肥 としてリン酸 $0.5 \mathrm{~kg} / \mathrm{a}$ を 1 回, 窒素 $0.6 \mathrm{~kg} / \mathrm{a}$ を 3 回に分 
けて施用した. 試験規模は作物研究センターでの 1 次ス クリーニン゙グが栽植密度 22.2 株 $/ \mathrm{m}^{2}$ の 1 本植えで, 1 区 規模が $4.5 \mathrm{~m}^{2}$, 現地での 2 次スクリーニングは栽植密度 17.4 株 $/ \mathrm{m}^{2}$ の 3 4 本 / 株植えで, 1 区規模は $100 \mathrm{~m}^{2}$ で 実施した。

\section{2）生育調查および加工特性検定}

最高分ほつ期および収穫期に，各供試品種・系統より それぞれ 10 株を抽出し, 草丈, 茎数, 葉色を調査した. 収穫後, $75^{\circ} \mathrm{C}$ で 10 時間乾燥し, 乾燥品の加工特性（草 長, 葉色, 手触り, しなやかさ, 葉先の揃い, つや）を 極良 6 〜不良 1 の 6 段階で評価した.

\section{4. 特性調査の結果}

1）作物研究センターにおける 1 次スクリーニング

表 1 に作物研究センターで実施した生育調査の概要と
供試年次を, 表 2 に特性検定の結果を示す.

熟期, 草丈, 茎数から判断した結果, 供試品種・系統 のらち「千石」,「神力」,「ビルマイネ」,「伊勢錦（見出 し)」,「広島もち (見出し)」,「宝満神社」が,「実取ら ず」との作期分散が可能で, しめ縄加工にも適すること が予想された。

このらち「伊勢錦（見出し）」は，出穗期が「実取ら ず」より 5 日遅く, 草丈は長く, 葉色も濃く推移するこ とから, しめ縄加工適応品種候補として最も注目された. 「宝満神社」は草丈が長く，茥数も多かったが，赤米で脱 粒性があり，また熟期が遅すぎて採種が極めて困難とな る可能性が考兄られた（表 1).

各品種・系統のしめ縄加工特性を調査した結果,「実 取らず」が最も高い評価を示し，「千石」，「瑞宝」，「伊集 赤穂」,「瑞穂」,「センボン」,「伊勢錦（見出し）」,「広島 もち (見出し)」がそれに次ぐ評価を示した.「センボン」 は「長さ」で「不良」の評価だったが，茎数が多く，葉

表 1. 供試品種・系統の生育特性

\begin{tabular}{|c|c|c|c|c|c|c|c|c|}
\hline \multirow[b]{2}{*}{ 品種·系統名 } & \multirow{2}{*}{$\begin{array}{l}\text { 出穂期 } \\
\text { (月・日) }\end{array}$} & \multicolumn{3}{|c|}{ 最高分げつ期 } & \multicolumn{3}{|c|}{ 収穫期 } & \multirow{2}{*}{$\begin{array}{c}\text { 調査年次 } \\
\text { (開始一終了) }\end{array}$} \\
\hline & & $\begin{array}{l}\text { 草丈 } \\
(\mathrm{cm})\end{array}$ & $\begin{array}{c}\text { 茎数 } \\
\left(\text { 本 } / \mathrm{m}^{2}\right)\end{array}$ & $\begin{array}{c}\text { 葉色 } \\
\text { (SPAD 值) }\end{array}$ & $\begin{array}{l}\text { 草丈 } \\
(\mathrm{cm})\end{array}$ & $\begin{array}{c}\text { 茎数 } \\
\left(\text { 本 } / \mathrm{m}^{2}\right)\end{array}$ & $\begin{array}{c}\text { 葉色 } \\
\text { (SPAD 值) }\end{array}$ & \\
\hline 実取らず & 8.21 & 85 & 447 & 36.9 & 109 & 371 & 32.2 & 1998-2002 \\
\hline 千石 & 8.30 & 85 & 377 & 39.2 & 105 & 338 & 34.5 & $1998-2002$ \\
\hline 端宝 & 8.22 & 82 & 400 & 37.8 & 106 & 346 & 31.6 & $1998-2002$ \\
\hline 大場もち & 8.13 & 91 & 189 & 36.1 & 112 & 184 & 34.1 & 1998-2000 \\
\hline 赤早生 & 8.22 & 100 & 302 & 34.0 & 122 & 255 & 31.2 & 1998-2000 \\
\hline 万倍 & 8.12 & 91 & 171 & 37.9 & 111 & 167 & 33.5 & $1998-2000$ \\
\hline 冷完ず & 8.10 & 91 & 167 & 36.6 & 111 & 171 & 33.4 & $1998-2000$ \\
\hline 伊集赤穂 & 8.18 & 91 & 226 & 32.8 & 116 & 200 & 31.0 & $1998-2000$ \\
\hline 端穗司 & 8.24 & 91 & 233 & 37.7 & 112 & 200 & 31.8 & $1998-2000$ \\
\hline 赤もち & 8.14 & 89 & 313 & 35.4 & 103 & 275 & 30.7 & $1998-2000$ \\
\hline 端穗 & 8.23 & 86 & 502 & 35.6 & 108 & 433 & 31.2 & $1998-2000$ \\
\hline ミトラズ & 8.23 & 82 & 486 & 33.7 & 103 & 417 & 31.6 & $1998-2000$ \\
\hline センボン & 8.23 & 63 & 502 & 34.7 & 79 & 486 & 32.7 & $1998-2000$ \\
\hline 神力 & 8.25 & 93 & 255 & 39.6 & 109 & 240 & 32.7 & $1998-2000$ \\
\hline ビルマイネ & 8.12 & 98 & 248 & 40.7 & 116 & 205 & 36.7 & $2000-2002$ \\
\hline GR2000-2 ${ }^{1)}$ & 9.10 & 87 & 299 & 37.7 & 105 & 268 & 30.6 & $2000-2002$ \\
\hline 緑稲 & 8.31 & 59 & 562 & 34.6 & 72 & 453 & 30.9 & 2000 \\
\hline 伊勢錦（見出し） & 8.26 & 99 & 188 & 43.5 & 123 & 183 & 36.6 & $2001-2002$ \\
\hline 広島もち（見出し） & 8.18 & 93 & 197 & 39.2 & 122 & 182 & 33.2 & 2001-2002 \\
\hline ヤナドリ & 7.23 & 75 & 216 & 38.3 & 84 & 184 & 41.3 & $2001-2002$ \\
\hline クロモチ & 7.26 & 76 & 214 & 39.4 & 87 & 184 & 41.7 & $2001-2002$ \\
\hline シミズモチ & 7.27 & 77 & 209 & 38.0 & 85 & 215 & 40.6 & 2001-2002 \\
\hline 宝満神社 & 9.06 & 93 & 493 & 41.2 & 141 & 386 & 31.3 & 2002 \\
\hline 秋田糯 79 号 & 7.23 & - & - & - & 77 & 289 & 41.8 & 2002 \\
\hline コシヒカリ & 8.07 & 73 & 411 & 40.6 & 96 & 397 & 39.0 & 2001 \\
\hline
\end{tabular}

1) 交配組合せ「山田錦／Bio-43」の後代育成系統. 
表 2. 供試品種・系統の加工特性

\begin{tabular}{|c|c|c|c|c|c|c|c|}
\hline \multirow{2}{*}{ 品種・系統名 } & \multicolumn{6}{|c|}{ 評価項目 1) } & \multirow{2}{*}{ 総得点 } \\
\hline & 長さ & 濃さ & 手触り & しなやかさ & 葉先揃い & つや & \\
\hline 実取らず & 5 & 5 & 5 & 5 & 4 & 5 & 29.0 \\
\hline 千石 & 5 & 5 & 4 & 5 & 4 & 5 & 28.3 \\
\hline 瑞宝 & 4 & 5 & 5 & 5 & 5 & 5 & 28.3 \\
\hline 大場もち & 5 & 5 & 3 & 3 & 4 & 3 & 22.0 \\
\hline 赤早生 & 6 & 4 & 4 & 3 & 3 & 3 & 23.3 \\
\hline 万倍 & 4 & 5 & 2 & 2 & 4 & 4 & 21.2 \\
\hline 冷えず & 6 & 6 & 2 & 2 & 4 & 5 & 24.7 \\
\hline 伊集赤穂 & 5 & 5 & 4 & 3 & 4 & 5 & 27.0 \\
\hline 瑞穂司 & 5 & 3 & 3 & 3 & 4 & 4 & 22.0 \\
\hline 赤もち & 3 & 3 & 4 & 4 & 4 & 4 & 22.7 \\
\hline 瑞穂 & 4 & 5 & 5 & 5 & 5 & 5 & 28.3 \\
\hline ミトラズ & 3 & 3 & 4 & 4 & 4 & 3 & 21.0 \\
\hline センボン & 1 & 5 & 6 & 6 & 6 & 5 & 29.0 \\
\hline 神力 & 4 & 3 & 3 & 3 & 4 & 4 & 21.0 \\
\hline ビルマイネ & 5 & 4 & 4 & 4 & 2 & 4 & 22.8 \\
\hline GR2000-2 & 3 & 3 & 3 & 3 & 4 & 3 & 18.7 \\
\hline 緑稲 & 1 & 5 & 5 & 5 & 5 & 5 & 25.7 \\
\hline 伊勢錦（見出し） & 6 & 6 & 3 & 2 & 4 & 5 & 26.0 \\
\hline 広島もち（見出し） & 4 & 4 & 4 & 4 & 5 & 5 & 26.3 \\
\hline ヤナドリ & 4 & 4 & 4 & 5 & 2 & 3 & 22.0 \\
\hline クロモチ & 4 & 5 & 4 & 5 & 2 & 3 & 23.0 \\
\hline シミズモチ & 4 & 5 & 4 & 5 & 2 & 3 & 23.0 \\
\hline 宝満神社 & - & - & - & - & - & - & - \\
\hline 秋田糯 79 号 & - & - & - & - & - & - & - \\
\hline コシヒカリ & 3 & 5 & 4 & 5 & 4 & 5 & 25.7 \\
\hline
\end{tabular}

1) 各評価項目について，極良：6，良：5, やや良：4, 中 : 3, やや不良 : 2, 不良 : 1 の 6 段階で評価.

先の揃いも極めて良く,「長さ」以外の評価項目で「実取 らず」以上の特性を示し，コンパクトなしめ縄加工製品 への適用性が高いものと考兄られた（表 2).

また，乙め縄加工には不適と評価されたものの，多様 な用途に利用可能と考兄られるものが認められた。「緑 稲」は草丈が短く，しめ縄加工特性も低かったが，穂が 鮮やかな紫色を呈し，穂数も多かったことから，景観資 源用稲として有望であった. 早生熟期の「ヤナドリ」,「ク ロモチ」,「シミズモチ」,「秋田糯 79 号」は草丈，茎数と もに乏しく，乙め縄加工への適用性は低かったが，葉色 が濃く，しなやかで手触りが良いことから，民芸品や郷 土玩具といったわら細工への適用性が高いものと判断さ れた（表 1,2）。

生育特性ならびに加工特性の調査結果から, 中山間地 域での利用価値が高いと判断した「千石」，「瑞宝」，「七 ンボン」,「神力」,「緑稲」，「伊勢錦（見出し）」，「ヤナド リ」,「クロモチ」,「シミズモチ」, 「宝満神社」の 10 品種 を現地実証試験（新潟県東頸城郡松代町）に供試した。

\section{2）現地実証試験における 2 次スクリーニング}

現地実証試験に打ける成績概要と供試年次を表 3 亿示 した．供試品種は現地実証試験においても，1 次スクリ一 ニングで得られた品種特性と同様な傾向を示したが，現 地慣行の極多肥栽培条件では「伊勢錦（見出し）」と「実 取らず」との出穂期の差が 1 日に縮小し，「実取らず」に 比べ，葉の退色が速い傾向が認められた. しかし，両品 種の出穗期は注湆同じであったが，最高分げつ期頃の草 丈は，「伊勢錦（見出し）」の方が $15 \mathrm{~cm}$ 以上長く，また 葉色も濃く，「実取らず」以上の特性を示したことから， 「実取らず」より 1 週間程度早く收穫しても加工上の問題 はなく, 収穫時期の分散化が図れるといら点で「有望」と 評価された（表 3 ).

各供試品種・系統について実際にしめ緡を作製し，そ の実用性について評価した結果，「伊勢錦（見出し）」に よるしめ縄は商品上極めて重要とされる「葉先の揃い」 に優れ，基部から先端部に至るまでの縄径が十分確保さ れており，付加価値の高いしめ縄加工製品の生産が可能 
表 3. 現地に扣ける生育

\begin{tabular}{|c|c|c|c|c|c|c|c|c|c|}
\hline \multirow[b]{2}{*}{ 品種·系統名 } & \multirow{2}{*}{$\begin{array}{l}\text { 出穗期 } \\
\text { (月・日） }\end{array}$} & \multicolumn{3}{|c|}{ 最高分げつ期 1) } & \multicolumn{3}{|c|}{ 収穫時 2) } & \multirow{2}{*}{ 総合評価 ${ }^{3)}$} & \multirow{2}{*}{$\begin{array}{l}\text { 調査年次 } \\
\text { (開始一終了) }\end{array}$} \\
\hline & & $\begin{array}{l}\text { 草丈 } \\
\text { (cm) }\end{array}$ & $\begin{array}{c}\text { 茎数 } \\
\left(\text { 本 } / \mathrm{m}^{2}\right)\end{array}$ & $\begin{array}{c}\text { 葉色 } \\
\text { (SPAD 值) }\end{array}$ & $\begin{array}{l}\text { 草丈 } \\
(\mathrm{cm})\end{array}$ & $\begin{array}{c}\text { 茥数 } \\
\left(\text { 本 } / \mathrm{m}^{2}\right)\end{array}$ & $\begin{array}{c}\text { 葉色 } \\
\text { (SPAD 值) }\end{array}$ & & \\
\hline 実取らず & 8.27 & 94 & 599 & 39.4 & 125 & 540 & 39.2 & & 2000-2002 \\
\hline 千石 & 9.02 & 102 & 622 & 40.3 & 128 & 511 & 36.5 & $\bigcirc \triangle$ & $2000-2001$ \\
\hline 瑞宝 & 8.24 & 94 & 661 & 39.8 & 122 & 538 & 37.2 & $\Delta x$ & 2001 \\
\hline センボン & 8.30 & 75 & 719 & 41.3 & 101 & 673 & 37.2 & $\triangle$ & 2000 \\
\hline 神力 & 8.23 & 100 & 338 & 41.5 & 126 & 322 & 39.4 & $\Delta x$ & 2000 \\
\hline 緑稲 & 9.04 & 75 & 760 & 42.5 & 90 & 656 & 40.8 & $x$ & 2000 \\
\hline 伊勢錦（見出し） & 8.28 & 111 & 365 & 43.6 & 138 & 325 & 37.7 & $\bigcirc$ & 2002 \\
\hline ヤナドリ & 7.25 & - & - & - & 96 & 418 & 41.6 & $\times$ & 2001 \\
\hline クロモチ & 8.02 & - & - & - & 110 & 404 & 42.9 & $\times$ & 2001 \\
\hline シミズモチ & 7.31 & - & - & - & 106 & 397 & 43.4 & $x$ & 2001 \\
\hline 宝満神社 & 9.10 & 87 & 442 & 42.9 & 122 & 451 & 41.8 & $x$ & 2002 \\
\hline
\end{tabular}

新潟県東頸城郡松代町千年に抢ける成績.

1) 7 月第 4 半旬に一括調査.

2) 早生種は 7 月第 4 半旬に, 晚生種は 8 月第 2 半旬に一括調査.

3) 乙め縄加工試験と熟期から見た総合的な評価; $\bigcirc$ : 有望, $\bigcirc \triangle$ : やや有望, $\triangle$ : 中, $\triangle \times$ : やや不適, $\times$ : 不適.

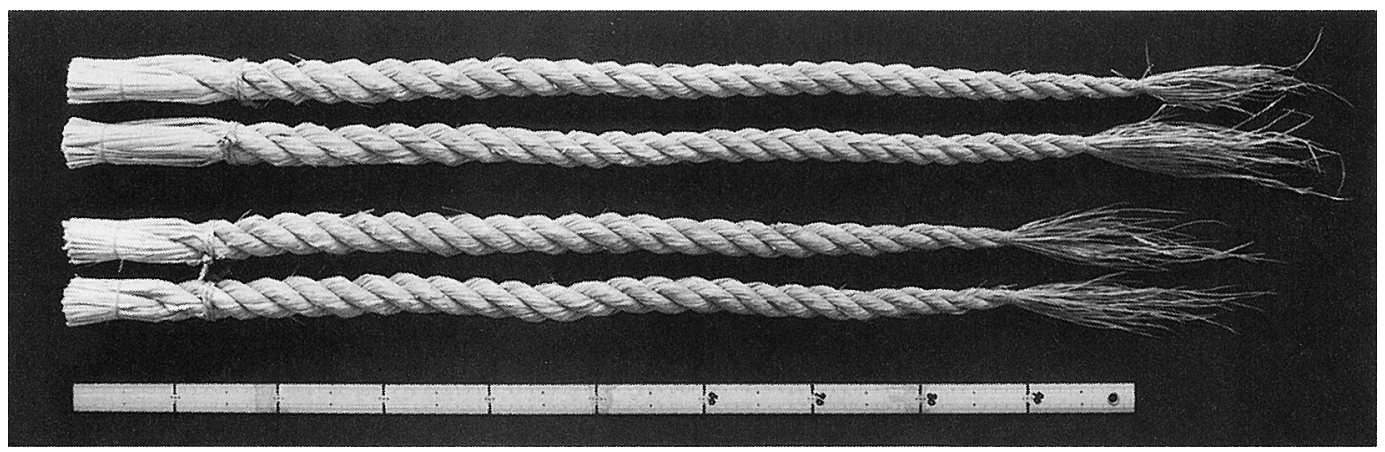

図 2. 松代町産「伊勢錦（見出し）」によるしめ縄加工製品（上段 : 伊勢錦（見出し），下段 : 実取らず）.

であった（図 2)。また，「千石」は葉色がやや淡いもの の，「実とらず」より熟期が遅く，生育量も大きく，葉が しなやかで扱いやすいことから「やや有望」との評価を 得た（表 3 ).

\section{5. 新たなしめ縄加工適応品種「伊勢錦（見出し）」 の特徴と栽培上の留意点}

\section{1）新潟県における「伊勢錦（見出し）」の特性}

本研究に供試した「伊勢錦（見出し）」は，2000年に 農業生物資源研究所・ジーンバンクから取り寄せた「伊 勢錦（保存番号 : 00007851, JP 番号 : JP7109）」の種子 を，作物研究センタ一に执いて試験栽培し，展開した個 体の中から, 途中生育と出穂 ·成熟期の揃い, おょび草 丈，茎数等によって選抜，採種した系統である. 原品種
「伊勢錦」との特性比較は実施していないが，品種登録出 願時の特性調査による 2 ランク以上の特性值の差はない ものと判断し，「伊勢錦 (見出し)」と称することとした. ここで表 4 および図 3 に, 新潟県に打ける「伊勢錦（見出 し)」の特性と稲姿を示す.

「伊勢錦 (見出し)」は「コシヒカリ」より出穂期が 20 日程度, 成熟期は 30 日程度遅く, 新潟県では晚生に属す る. 極めて長稈で穂長も長いが，穂数は少ない，収穫時 の乾物重は「実取らず」より若干軽いものの, 生育量が 大きいことから, 乾燥品の収量性に問題はないものと考 えられる、葉いもち耐病性は弱である。加工特性は「実 取らず」に比べ，手触りとしなやかさが劣るものの，葉 が長く，葉先の揃いが良く，つやも良好で，十分なしめ 縄加工特性を有する (表 4). 
表 4.「伊勢錦（見出し）」の特性概要

\begin{tabular}{|c|c|c|c|c|}
\hline & & $\begin{array}{c}\text { 伊勢錦 } \\
\text { (見出し) }\end{array}$ & 実取らず & コシヒカリ \\
\hline \multicolumn{2}{|c|}{ 熟 期 } & 晚生 & 晚生 & 中生 \\
\hline \multicolumn{2}{|c|}{ 草 型 } & 穗重型 & 偏穂重型 & 中間型 \\
\hline \multicolumn{2}{|c|}{ 出穂期（月－日） } & 8.26 & 8.23 & 8.07 \\
\hline \multicolumn{2}{|c|}{ 成熟期（月・日） } & 10.08 & 10.05 & 9.11 \\
\hline \multicolumn{2}{|c|}{ 㷏＼cjkstart長（cm） } & 134 & 112 & 91 \\
\hline \multicolumn{2}{|c|}{ 穂 長 (cm) } & 23.3 & 18.6 & 18.7 \\
\hline \multicolumn{2}{|c|}{ 穂 数 $\left(\right.$ 本 $\left./ \mathrm{m}^{2}\right)$} & 158 & 306 & 358 \\
\hline \multicolumn{2}{|c|}{ 芒の多少・長短 } & 無 & 中. やや短 & 稀・短 \\
\hline \multicolumn{2}{|c|}{ 方先色 } & 褐 & 紫 & 黄白 \\
\hline \multicolumn{2}{|c|}{ 脱粒性 } & 難 & 中 & 難 \\
\hline \multirow{3}{*}{$\begin{array}{l}\text { 最高 } \\
\text { 分ぼ } \\
\text { つ期 }\end{array}$} & 草丈（cm） & 99 & 84 & 73 \\
\hline & 茥数 $\left(\right.$ 本 $\left./ \mathrm{m}^{2}\right)$ & 188 & 421 & 411 \\
\hline & 葉色（SPAD 值） & 43.5 & 37.9 & 40.6 \\
\hline \multirow{4}{*}{$\begin{array}{l}\text { 収 } \\
\text { 穫 } \\
\text { 期 }\end{array}$} & 草丈（cm） & 123 & 109 & 96 \\
\hline & 茎数 $\left(\right.$ 本 $\left./ \mathrm{m}^{2}\right)$ & 183 & 330 & 397 \\
\hline & 葉色（SPAD 值） & 36.6 & 31.2 & 39.0 \\
\hline & 乾物重 $\left(\mathrm{kg} / \mathrm{m}^{2}\right)$ & 0.66 & 0.72 & 0.61 \\
\hline \multicolumn{2}{|c|}{ 下葉枯れ } & 中 & 中 & やや少 \\
\hline \multicolumn{2}{|c|}{ 葉いもち1) } & 弱（7.5） & 弱（8.7） & 弱（5.4） \\
\hline 加 & 手触り & 中 & 良 & やや良 \\
\hline 工 & しなやかさ & 中 & 良 & 良 \\
\hline 特 & 葉先の揃い & 良 & やや良 & やや良 \\
\hline 性 & つや & 良 & 良 & 良 \\
\hline \multicolumn{2}{|c|}{$\begin{array}{l}\text { 調 査 地 } \\
\text { 調査年次 }\end{array}$} & $\begin{array}{l}\text { 県農業総合 } \\
\sim 2002 \text { 年, }\end{array}$ & $\begin{array}{l}\text { 研究所作物研 } \\
\text { コシヒカリ }\end{array}$ & $\begin{array}{l}\text { 究センター } \\
\text { は2000 年 }\end{array}$ \\
\hline
\end{tabular}

収穫期 : 最長秙の幼穂長 $5 \mathrm{~cm}$.

加工特性 : 極良〜不良の 6 段階評価.

${ }^{1)}$ 括弧内の数字は葉いもち特性検定試験（畑晚播法）に抢ける 発病程度.

\section{2）栽培上の留意点と期待される導入効果}

「伊勢錦（見出し）」は，「実取らず」に比べて茎が太 く, 慣行栽培となっている多肥条件下では「実取らず」よ り葉色の退化が早いことから（表 3)，刈り取り適期を逃 さないよら注意する必要がある。 また，葉いもち耐病性 が弱であることから，病斑による商品価値の低下を防ぐ ため, 葉いもち病予防防除の徹底を心がける必要がある。

「伊勢錦（見出し）」の導入は，「実取らず」との作期分 散を可能とし, しめ縄イネの栽培面積の拡大により, 中 山間地域に和ける水田機能の維持と地場産業のさらなる 発展を図ることができる.

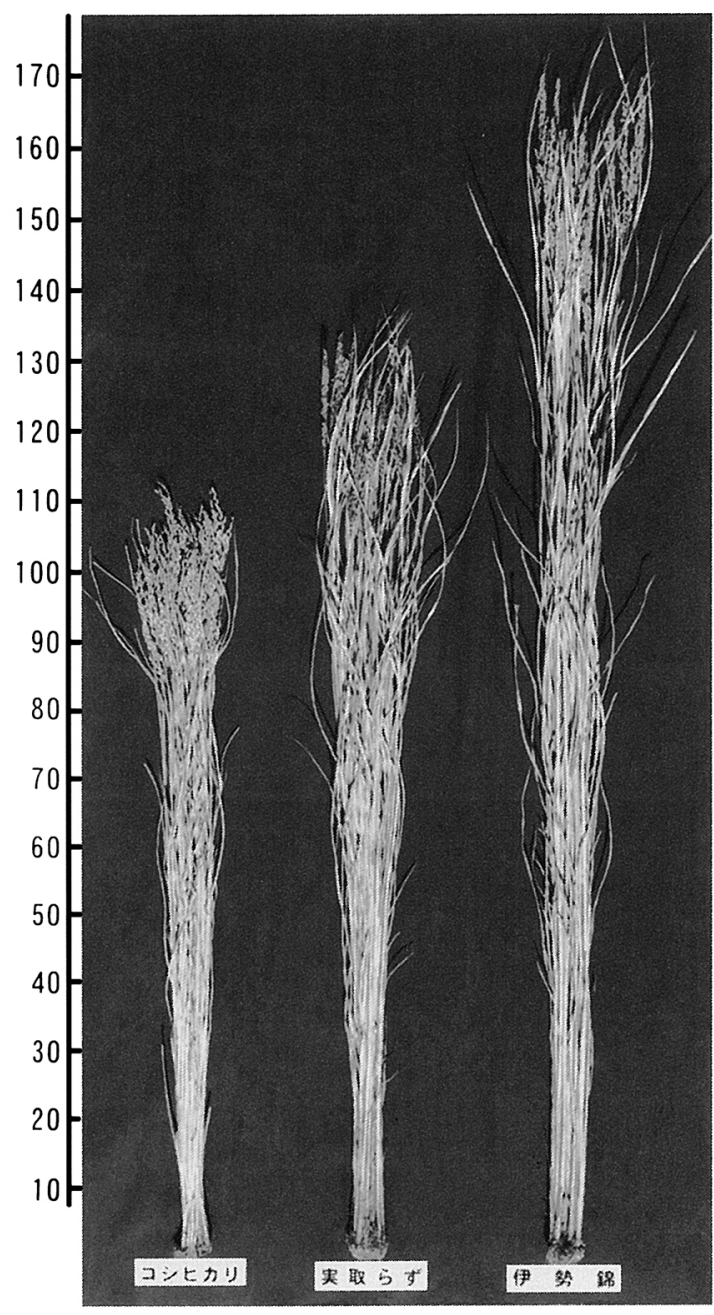

図 3.「伊勢錦（見出し）」の稲姿.

\section{6. 今後の課題と将来展望}

木研究により，しめ縄加工適応品種として選出した 「伊勢錦」は，元々は三重県の篤農家・岡山友清が 1860 年に「大和」より選抜したとされる品種で，1900 年代の 初めには三重県を中心に 1 万 4 千ヘクタール余りの作付 けがあった．大粒であることから，当初より酒造用原料 米として用いられ，現在でも酒造用として三重県内で数 ヘクタールの小規模な作付けが認められる（米穀データ バンク 1999).

本研究では，5力年にわたり，優れたしめ縄加工特性 を有するイネ遺伝資源のスクリーニングを行い，最終的 に「伊勢錦」を選出した。「伊勢錦」は，酒造用以外にも， 伊勢神宮の参拝者向けの「わら年らり」の原材料として も重用された歴史があり，こうした従来からの経験的な わら加工特性の高さが，本研究によっても認められたと 言える.

新潟県では，「伊勢錦（見出し）」による「実取らず」 との作期分散によって, 現在 $200 \mathrm{ha}$ 程度認められている しめ縄イネ武培面積の約 3 割に相当する $60 \mathrm{ha}$ 程度が，新 
たなしめ縄イネ栽培面積として上積みできるものと期待 される. 一方しめ縄製品は, その消費地によって型式に 違いがあり，加工現場ではそれぞれの要望に応じた多種 類の製品を生産しなければならず，今後，「伊勢錦（見出 し)」についての各種しめ縄加工形態への適応性を検討 する必要かある。また，「伊勢錦（見出し）」は「実取ら ず」に比へミて，葉色のさめが早い傾向が認められること から，葉色を保持する栽培管理方法の確立と，葉いもち 病に強く，葉色がさめにくい新たなしめ縄加工適心品種 の探索，あるいは育成を行う必要がある. さらに，乾燥 品の緑色保持技術の開発を支援するといら課題も残され ている. こうした問題点を解決し, 地域農業の活性化を さらに推進してゆくためには，これまで以上に密接な生 産現場, 普及組織, 試験研究機関の連携が重要である.

農林水産技術情報協会（1999）や農業生物資源研究所 （2002）の報告を見ても，しめ縄加工といら特殊用途につ いてのイネ遺伝資源の特性評価が行われた実績は見当た らない。現代稲作では，機械化栽培適性の向上を図る目 的から品種の短㷏化が顕著に進み, 本研究で対象とした ようなしめ縄やわら加工に適すると考它られる長稈・晚 性のイネ品種は, 在来種や旧来品種に頼らざるを得ない. 当センタ一に拈いても, 新潟県内のイネ遺伝資源の探 索・収集を行い, 地域の遺伝資源の調査や保存活動を 行ってきたが，その規模は小さく，遺伝的多様性は極め て限定的である. 幸い本研究においては「千石」,「セン ボン」,「緑稲」など, 当センターが所有する収蔵品の中 にも注目すべき品種・系統が認められたが, 最も有望と 評価された品種はジーンバンクの遺伝資源の中から選出 された.

新潟県ではこれまでにも，「亀の尾」や「菊水」など， ジーンバンクより取り寄せた品種が酒造用原料米として 有効に利用され，地域農業の活性化に大きく寄与してい るといら実績がある．本研究による「伊勢錦（見出し）」 の選出は, 当県の農業振興に扣けるジーンバンク事業の 重要性をあらためて認識させるとともに, 多様なイネ遺 伝資源に新たな価值を見出し，イネ育種素材として利用 してゆくといら研究分野の重要性を提起するものであ
る.

元来「伊勢錦」は酒造用原料米として広く知られた品 種であったが，本研究により，新たにしめ縄加工特性も 高いことがわかった. 一方, 新潟県中魚沼郡のある地域 は大相撲の土俵に用いるたわら用の稲わらの主産地で, 現地ではやはり「実取らず」を多く用いてきたが，腐食 が早いことから，土俵際の激しい攻防にも耐光らるたわ らを編むことがでさるイネ品種を長らく求めていた。 そ こで，本研究で選出した「伊勢錦（見出し）」を含む複数 の品種について，耐久性や耐腐食性といった，しめ縄加 工とは全く異なる利用方法での実用化試験が進められて いる. 本研究で選出した「伊勢錦（見出し）」には，こう した新たな用途への適応性も期待されている.

新潟県のしめ縄イネ栽培は，「伊勢錦（見出し）」を導 入したとしても 300 ha に満たない規模であるが，我が国 の伝統文化を支学貴重な農業生産活動であり, こうし た地域の特色を活かした多様な農業の形態を育種研究の 立場から支援することは，極めて大きな意義を持つもの と考觉る.

\section{謝 辞}

本研究の供試品種選定にあたり, 独立行政法人・農業 生物資源研究所・ジーンバンクの長峰司上席研究官に貴 重なご助言を頂いた．ここに記して感謝の意を表する.

\section{引用文献}

戸倉一泰 (2002) 育種学研究 4 (2) : 95-99.

農業生物資源研究所 (2002) “平成 13 年度農業生物資源ジーンバ ンク事業実績報告書” 独立行政法人農業生物資源研究所, 茨城. $76 \mathrm{p}$.

農林水産技術情報協会 (1999) “平成 10 年度農林水産ジーンバン ク事業の植物遺伝資源の地域振興作物スクリーニング等委 託事業成果報告書” 社団法人農林水産技術情報協会, 東京. $120 \mathrm{p}$.

米穀データバンク（1999）“米品種大全 2 米穀データバンク，東 京. 256 